\title{
THE COSTS AND REIMBURSEMENTS FOR LUNG CANCER TREATMENT AMONG SELECTED HEALTH CARE PROVIDERS IN THE CZECH REPUBLIC
}

\author{
Jana Šimrová, Miroslav Barták, Radovan Vojtíšek, \\ Vladimír Rogalewicz
}

\section{Introduction}

Lung cancer is the most frequently diagnosed oncologic disease worldwide. It is annually diagnosed in nearly 1.4 million patients. It is also the most frequent cause of cancer related deaths [32]. In the Czech Republic, lung cancer occupies a leading position both in the rate of incidence and the mortality rate. In men, it is the second most common oncologic disease after prostate cancer, while in women it assumes third position after breast and colon cancer [31]. Lung (bronchogenic) carcinoma are generally divided into two basic types: a group of non-small-cell lung cancers (NSCLC), which contributes to the total number of lung cancers at the level of 75 to $80 \%$, and the small-cell lung cancer (SCLC) accounting for the remaining 20 to $25 \%$. Both types differ from each other in regard to the biological behaviour and prognosis, as well as the treatment strategy [30], [31]. In 2010, the incidence of this disease in men was 89.7 per hundred thousand people (it was 102.3 in 1996), while in women it was 35.2 per hundred thousand people (against 22.9 in 1996). The severity of the disease is also reflected by the high mortality rate which was 74.8 per hundred thousand people in men in 2010 (87.9 in 1996) and 27.4 per hundred thousand people in women (19.5 in 1996) [28].

Cancer costs the EU are estimated as 126 billion EUR in 2009, with health care accounting for 51 billion EUR. Lung cancer had the highest economics cost 18.8 billion EUR. [11]. Up until this point (second part of the year 2013), no comprehensive study of healthcare costs for lung cancer treatment in all stages of the illness has been published in the Czech Republic. The main object of this study is to make an assessment of therapy related costs from the payers' (health insurance funds) and the healthcare providers' (hospitals) perspective based on some available and identifiable data from three out of total thirteen Complex Oncology Centres in the Czech Republic, namely Brno, Hradec Králové and Plzeň, where the treatment standards were set up [5], [20], [21], [30].

Several international studies have been carried out in the European context using, as a rule, so-called treatment algorithms for the determination of therapeutic costs [1]. Based on these algorithms, prices were successively analysed applying mainly the analysis of reimbursements based on DRG or on published reimbursement lists [14], [25], [29]. All the studies mentioned here are based on cost estimates. German study assessing the social costs employed the principle based on assessing the rate of human capital. The total costs, including the absenteeism costs, were thereby assessed. [27]. A retrospective study carried out in the Netherlands assessed costs from the initial diagnosis to subsequent death or to the end of the assessment period. It included the length of hospital stays, the types and number of diagnostic procedures involved and some information concerning radiotherapy and chemotherapy [23]. A very widespread approach is the assessment of treatment in a particular stage [1]. The authors of a study on this topic carried out in Switzerland came to the 
conclusion that a hospital stay is inexpedient in terms of cost effectiveness [9]. In the UK and the US, the so-called global studies analyse also the social costs of lung cancer [4]. The most extensive study of this type was published in the USA, by means of the application of diagnostic and therapeutic algorithms, the results of which were supported by data from a group of over 2,000 patients [15]. A study written in Thailand, describes a sample group of $96 \%$ of all patients with lung cancer registered there in 2010. The treatment costs were subdivided according to three schemes currently employed in Thailand for healthcare reimbursement [22].

According to Cipriano et al. [6], the monthly treatment costs for a 72-year-old patient diagnosed with lung cancer in 2000, ranged from USD 2,687 (no active treatment) to USD 9,360 (chemo-radiotherapy) in the first 6 months; costs varied by stage at diagnosis and histologic type.

Vergnenègre et al [29] used a sample from public and private hospitals treating large numbers of patients. The study covered the period from 1 July 1998 to 30 June 1999, and was based on medical chart review. A Markov model with six decision trees (two for small cell lung cancer [SCLC] and four for non-small cell lung cancer [NSCLC]) was used for the cost analysis. The treatment was broken down into first-line and second-line strategies, surveillance, and terminal care (TC). The resulted average management costs were EUR 22,006 (EUR 10,631-36,296) for 1 year and EUR 25,643 (EUR 10,631-41,191) for 2 years. The 2-year average costs were EUR 22,420 for disseminated SCLC and EUR 27,098 for localized SCLC. The costs of NSCLC ranged from EUR 19,543 for nonsurgical stages to EUR 30,024 for surgical stages, and to EUR 24,383 for stage IV. The weight of the different components of each strategy differed markedly according to the diagnostic subgroup: the cost of diagnosis ranged from $7.4 \%$ to $14 \%$ of the total management costs, and that of TC ranged from $11.5 \%$ to $31.1 \%$. The principal cost component was the first-line chemotherapy (32-58.5\%). Sensitivity analyses showed that, whatever the type of lung cancer, the percentage of actively treated patients was the main cost determinant. TC and chemotherapeutic lines also had important economic implications.
Dedes et al. [9] concluded that for the entire patient sample in his study, the mean cost per patient was EUR 19,408 (median EUR 14,691, range EUR 1,821-80,020), $71 \%$ of which was due to the hospitalisation costs. The mean cost per a NSCLC patient was EUR 19,212 (median EUR 14,511, range EUR 1,821-80,020), and per a SCLC patient it was EUR 20,992 (median EUR 15,367, range EUR 5,282-51,840).

Wolstenholme and Whynes [33] published a detailed patient-by-patient cost analysis based on case records for 253 patients diagnosed in 1993, revealing that the mean 4-year diagnosis and treatment costs amounted to GBP 6,150 and GBP 5,668 for non-small cell and small cell lung cancer resp. These costs are lower than those identified in Canadian studies, the difference being explained by the use of simulated costing methodology, lower unit costs, and less aggressive interventions.

Zeng et al [34] calculated the mean cost of treatment for PFS and DPS patients; over one year it was approximately USD 11,566 and USD 14,519, respectively. The monthly costs for all patients were higher initially than in the subsequent months (PFS: USD 2,490; DPS: USD 2,503). For PFS patients, healthcare expenditures stabilised after the 7th month, with the mean monthly medical expenditure of USD 82.49. For DPS patients, expenditures stabilised after the 9th month, and the mean expenditure during the 9th month was USD 307.9. Medical care costs in the three successive months prior to death were USD 3,754, USD 5,829 and USD 7,372, respectively.

The majority of economic studies devoted to lung cancer include only direct costs using either simple cost-minimisation analyses, or complex cost-benefit analyses [3], [17]. Specific eligible costs vary between individual studies and countries. The underlying reasons may be seen in different data sources, a different organisation of the health care system, its financing and reimbursements [17]. The studies vary also e.g. according to the respective patients' populations, the types of analyses, approaches or time horizons, or by the afore mentioned type of costs involved [4].

An OECD study published in 2013 summarised that cancer currently consumes around $5 \%$ of all health care costs. Increasing incidence, prolonged survival, and high costs of novel drugs and technologies mean that growth 
in spending on cancer is outstripping growth in total health expenditure. Cancer patients and their carers also bear significant costs, both financial and social. Once these are taken into account, the global economic impact of premature death and disability from cancer is around USD 900 billion, larger than that for heart disease, [19]. The conclusions of the OECD report are based on estimates of health care related cost data. This is considered a problem based in unavailability of actual data, and the report stresses the importance to move towards an implementation of disease specific health accounts in the future.

In Europe it is generally accepted that the cost assessment should be left to the national bodies, while the outcomes can be shared, as they are usually results of a multi-centre randomized controlled trial. E.g. the panel of V4 experts [10] concluded in December 2011 that “... HTA decision making should be left to the national level. This is due to varying standards, costs, traditions and values." Also the study carried out by Schiller et al. [25] concluded that differences in healthcare systems cause that the results of cost/financial analyses may not be generalizable to all countries/settings.

\section{Methods and Sources of Data}

Based on the analysis of the studies above, a methodology was set up with the objective of assessing costs for lung cancer treatment, both from the payers' and the healthcare providers' perspectives. In the Czech Republic a similar methodology was used in the study dealing with costs of type II diabetes in 2009 [12]. We also followed the methodological recommendations formulated by the 2013 Report of the ISPOR Health Economic Evaluation Publication Guidelines Good Reporting Practices Task Force. [13]

The costs spent in the Czech Republic by the payer (health insurance funds) may be calculated on the basis of publicly accessible data, i.e. particularly the Decree No. 134/1998 Coll., which issues the list of medical procedures with their point values [8]. This decree is annually updated, and the calculations in this study are based on some relevant data for 2013. The calculations using DRG codes are based on information published on the website of the National Reference Centre (NRC). It primarily includes the codebook of relative weights and the list of general tariffs of the costs for services [18]. For the purposes of the lung cancer therapy calculation, the calculations were made excluding complications and comorbidities (hereinafter CC). The costs of pharmaceuticals were included in all models. Just in the case of hospital overhead estimations, these costs were omitted due to the danger of possible overestimation of the hospital total overhead costs. In bronchogenic carcinoma, complications and associated diseases are highly individual and their costs must be monitored separately so they were excluded from the calculations. In the case of chemotherapy, it must be said that all costs for pharmaceuticals (including biological therapy) are paid separately and, therefore, they are included in individual calculations in this way.

It is, however, much more difficult to identify the costs spent by the health care provider, as the majority of hospitals and health care facilities work with cost related data in the "confidential" mode. For the purposes of this study, these costs were estimated and verified based on expert opinions of pulmonologists, oncologists, head physicians and staff members of technical and economic departments of two pneumooncologic centres and three university hospitals in the Czech Republic. Interviews with experts were conducted in the period from November 2012 to February 2013 based on diagnostic and therapeutic algorithms (whose selection is described in the part Results) thanks to which costs for individual interventions were specified. To attain the total costs, overhead costs had to be added. Based on consultations with experts, overhead costs were additionally calculated to include all costs, excluding drugs, i.e. mainly chemotherapeutics and biological drugs. These pharmaceuticals (primarily biological drugs) form the dominant part of costs in numerous therapeutic procedures. If overhead costs were added to them, some results would arise and be unlikely costs for therapy. In the final consequence, the real situation would not be reflected in this way.

The times of interventions are stated in accordance with the data published in the lists of procedures with point values for individual medical branches [2], [8]. The salaries of medical staff are calculated based on average salaries and wages for 2011 published by the Institute of Health Information and Statistics of 
the Czech Republic [16] (the latest data released to date).

The calculated costs were noted directly into the process maps; see an example in Figs. $1-3$. The first figure presents all options of the therapeutic scheme for the stage IIIB. Here, individual calculations are not described for the reason that they are specified in the following therapeutic paths that follow from the basic chart. Thus, the maps below (Fig. 2 and Fig. 3) display two different paths that the clinician may select during the treatment of bronchogenic carcinoma in stage IIIB. In them, the costs for the individual steps are already demonstrated. If the schemes include a step without the accompanying calculated costs, it is not a therapeutic procedure. In this stage, it is an intermediate step due to diagnostics. The costs for these diagnostics are negligible if compared with the costs for treatment as such.

All the data are expressed in Czech Crowns (CZK). The CZK exchange rate ranged between 25-26 CZK to EUR, or 19-20 CZK to USD during the previous year [7]. All monetary data were rounded to the nearest crown.

\section{Fig. 1: Non-small-cell type of lung cancer - stage IIIB; basic chart}

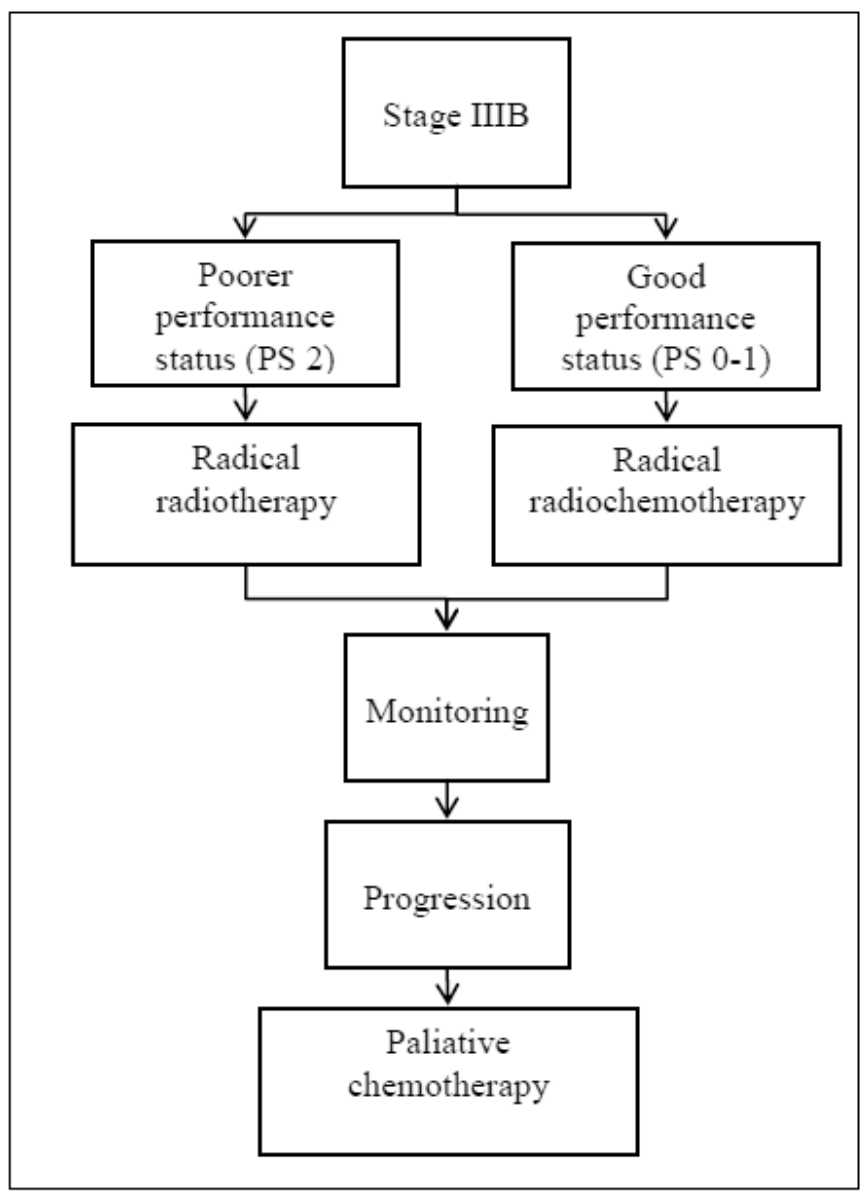

Source: Authors' design based on recommended therapeutic procedures [5], [20], [21], [30] 


\section{Fig. 2: Non-small-cell type of lung cancer - first therapeutic path for stage IIIB}



Source: Authors' design based on recommended therapeutic procedures [5], [20], [21], [30]

\section{Results}

The results presented in this study are calculated based on some diagnostic and therapeutic algorithms, i.e. process maps. These, in turn, were designed, based on recommended therapeutic procedures issued by the Masaryk Institute of Oncology, the University Hospital in Hradec Králové and the University Hospital in Plzeň [5], [20], [21], [30]. Based on these issued therapeutic standards, these maps were modified into their current form. Procedures are subdivided according to the above mentioned basic types of the disease into small-cell lung cancer (SCLC) and nonsmall-cell lung cancer (NSCLC). Each procedure consists of diagnostics, therapy and the subsequent monitoring of patients. The costs for such respective steps were assessed in individual blocks, and the total costs for the particular therapeutic scheme were subsequently calculated.

As an example, the therapeutic algorithm for stage IIIB of NSCLC (Fig. 1-3) is demonstrated. An entire set of process maps 


\section{Fig. 3: Non-small-cell type of lung cancer - second therapeutic path for stage IIIB}

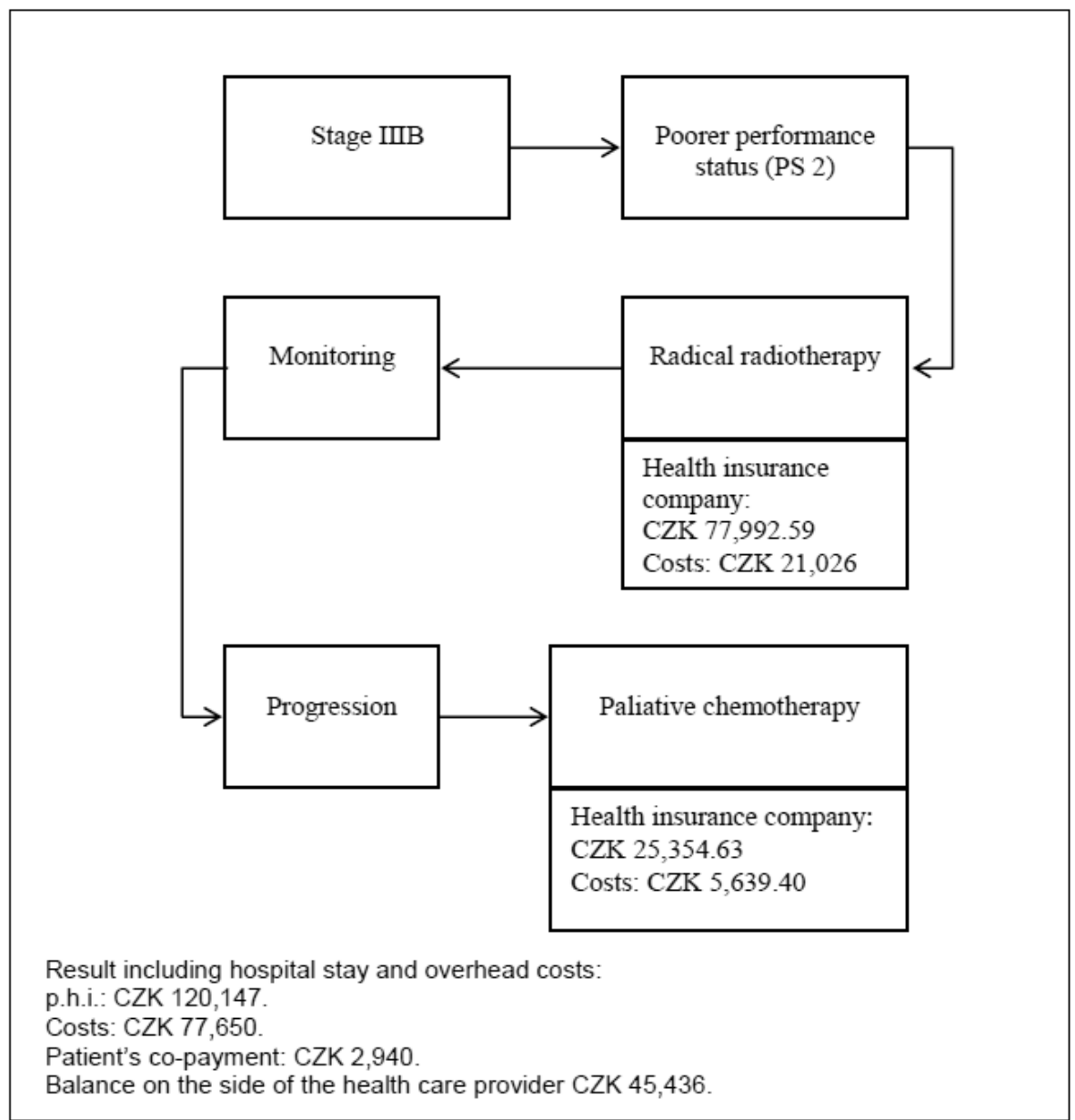

Source: Authors' design based on recommended therapeutic procedures [5], [20], [21], [30]

may be found in [26]. All calculations are always based on the basic algorithm which is successively subdivided into such individual diagnostic or therapeutic paths. These paths allowed us to calculate the costs for individual therapeutic alternatives which a patient may undergo. The term path is used in this context to describe the therapeutic process undergone by an individual patient based on a clinician's recommendations involving standard therapeutic procedures. Hence, a path describes one of the alternatives that a patient may undergo.
Algorithms in Figs. 1-3 are compiled according to the above mentioned data capturing the recommended diagnostic and therapeutic procedures for stage IIIB of NSCLC. The calculation of all the other recommended alternatives (depending on the type and stage of the disease) followed the same principle.

Using the procedure above, the costs for 32 utilized procedures (process maps) were calculated. The costs for therapeutic processes account for 22 results, while diagnostic procedures account for 10 results. Both direct 
and indirect costs were included in some individual calculations. The overview of costs for all 32 processes is presented in Tabs. 1 and 2 , whereby costs on the part of the health care provider, health insurance payments $(=$ the payer's costs), patient's co-payments, and the balance in the provider's favour are included. The patient's co-payment (regulatory fee) depends on the average time of treatment in relation to which the numbers of regular medical check-ups and the presumed length of hospital stays are determined.

\section{Tab. 1: Non-small-cell type of lung cancer: complete results (all data are in CZK)}

\begin{tabular}{|c|c|c|c|c|}
\hline Type of procedure & Costs & $\begin{array}{l}\text { Payment from } \\
\text { instance }\end{array}$ & Co-payment & Balance \\
\hline Dg. Path 1 & 32,926 & 33,726 & 0 & 800 \\
\hline Dg. Path 2 & 25,766 & 25,539 & 0 & -226 \\
\hline Dg. Path 3 & 19,336 & 21,684 & 0 & 2,348 \\
\hline Dg. Path 4 & 26,496 & 29,871 & 0 & 3,375 \\
\hline Therapy IA Path 1 & 120,950 & 155,256 & 2,940 & 31,366 \\
\hline Therapy IA Path 2 & 77,673 & 108,602 & 5,290 & 25,639 \\
\hline Therapy IA Path 3 & 138,110 & 169,065 & 5,290 & 25,666 \\
\hline Therapy IB-IIIA Path 1 & 120,950 & 155,255 & 2,940 & 31,365 \\
\hline Therapy IB-IIIA Path 2 & 103,691 & 91,073 & 5,290 & $-17,907$ \\
\hline Therapy IB-IIIA Path 3 & 132,493 & 169,065 & 5,290 & 31,282 \\
\hline Therapy IB-IIIA Path 4 & 132,493 & 169,066 & 5,290 & 31,283 \\
\hline Therapy IIIB Path 1 & 100,401 & 96,459 & 2,940 & $-6,882$ \\
\hline Therapy IIIB Path 2 & 71,770 & 120,147 & 2,940 & 45,437 \\
\hline Therapy IV Path 1 & 69,487 & 94,792 & 2,700 & 22,605 \\
\hline Therapy IV Path 2 & 519,810 & 579,040 & 2,700 & 56,530 \\
\hline Therapy IV Path 3 & 582,050 & 608,075 & 2,700 & 23,325 \\
\hline Monitoring for T1 N0 & 82,723 & 86,028 & 0 & 3,305 \\
\hline Monitoring - inoperable dinase & 69,704 & 78,256 & 0 & 8,523 \\
\hline Monitoring of metastases & 55,354 & 63,872 & 0 & 8,518 \\
\hline
\end{tabular}

Source: Authors' calculation based on the procedure described in the sections Methodology and Results.

Remark: TNM - international classification of the disease extent

$\mathrm{T} 1 \mathrm{NO}$ - disease in the least possible stage

The DRG system sets "average" reimbursements for all procedures (diagnostic and therapeutic) connected with the given diagnosis (weighted average depending on the number of patients in individual alternatives). By its very nature, therefore, the health insurance company does not consider different alternative therapies, but acknowledges on behalf of the hospital a "standardised" reimbursement for any type of treatment for the given diagnosis. The system according to the authors was that deviations from the average would be mutually compensated, and this system would simplify all reporting. It is not the purpose of this article to describe the actual handling of the DRG system in the whole system within the Czech health care system, nor in individual hospitals. In general we do not mind that the reimbursement of the care is underestimated. In terms of the diagnostics and treatment of bronchogenic carcinoma, only 6 diagnostic groups come into account presented in Tab. 3 (CC standing for complications and commorbidities). 
Tab. 2: Small-cell type of lung cancer: complete results (all data are in CZK)

\begin{tabular}{l|c|c|c|c}
\hline Type of procedure & Costs & $\begin{array}{c}\text { Payment from } \\
\text { insurance }\end{array}$ & Co-payment & Balance \\
\hline Dg. Path 1 & 16,324 & 16,681 & 0 & 357 \\
\hline Dg. Path 2 & 22,754 & 20,778 & 0 & $-19,758$ \\
\hline Dg. Path 3 & 33,754 & 32,147 & 0 & $-1,606$ \\
\hline Dg. Path 4 & 27,324 & 26,091 & 0 & $-1,233$ \\
\hline Therapy for an extensive disease Path 1 & 102,685 & 107,985 & 2,255 & 3,046 \\
\hline Therapy for an extensive disease Path 2 & 73,008 & 51,120 & 2,255 & $-24,143$ \\
\hline Therapy for an extensive disease Path 3 & 80,658 & 109,555 & 2,255 & 26,642 \\
\hline Therapy for a limited disease Path 1 & 130,096 & 177,954 & 2,549 & 45,309 \\
\hline Therapy for a limited disease Path 2 & 138,657 & 239,738 & 2,549 & 98,532 \\
\hline Therapy for a limited disease Path 3 & 90,246 & 104,635 & 2,549 & 11,840 \\
\hline Therapy for a limited disease Path 4 & 122,308 & 183,580 & 2,549 & 58,722 \\
\hline Monitoring of a limited disease & 21,375 & 23,200 & 0 & 1,825 \\
\hline Monitoring of an extensive disease & 2,553 & 2,733 & 0 & 180 \\
\hline
\end{tabular}

Source: Authors' calculation based on the procedure described in the sections Methodology and Results.

Reimbursements are calculated applying the following formula:

$D R G$ reimbursement $=$ cost weight $\times($ basic rate + additional factors $)$

Tab. 3: Reimbursements using the DRG system

\begin{tabular}{l|c} 
Group & Reimbursement amount \\
\hline Radiotherapy without CC & $1.2552 \times(37,279+1,497)=$ CZK 48,672 \\
\hline Chemotherapy without CC & $0.6824 \times(20,269+10,917)=$ CZK 21,281 \\
\hline Major chest surgery without CC & $3.1129 \times(92,453+12,812)=$ CZK 327,679 \\
\hline Minor chest surgery without CC & $2.5833 \times(76,725+15,220)=$ CZK 237,522 \\
\hline Malign diseases of respiratory system without CC & $0.6493 \times(19,285+1,752)=$ CZK 13,659 \\
\hline $\begin{array}{l}\text { Syndromes, symptoms and other diagnoses of the } \\
\text { respiratory system without CC }\end{array}$ & $0.4140 \times(12,296+222)=$ CZK 5,182 \\
\hline
\end{tabular}

Source: NRC and authors' calculation

\section{Discussion}

The study presents some cost calculations for individual diagnostic and therapeutic procedures at different stages of bronchogenic carcinoma. The calculations of disease related costs are always based on one standard treatment algorithm that is recommended and typical of the particular patient's performance status. Genuine patients with lung cancer, however, continuously fight the disease and, therefore, they participate in several of these therapeutic schemes. The treatment in practice may differ from recommended standards as the clinician must react to the patient's current status at any given moment. Moreover, there are other symptoms that usually also interfere in the course of such severe diseases, and it is very difficult to distinguish whether they have been caused by the tumour or are independent of it. This, however, does not affect the calculation of the cost rates for the individual stages in the therapeutic process.

In the case of SCLC and NSCLC diagnostic procedures, the assumption that the health 
care provider covers their costs may be confirmed with a high level of reliability. Diagnostic methods may be divided into imaging, laboratory and surgical methods. The reimbursements for imaging and surgical diagnostics cover actual costs of the health care providers. With respect to laboratory methods, this is not necessarily the case. Based on our own calculations, we estimate that the reimbursement represents a mere $61 \%$ of the incurred costs. The costs for laboratory methods are not essential for the health care providers as they account for a relatively small portion of the total costs that mainly include the costs for therapies.

A more detailed analysis of costs relating to non-small-cell lung cancer revealed that the health care provider's financial balance is predominantly positive. These are usually amounts with a maximum positive balance of CZK 56,530. However, the total costs on the part of hospitals, as well as payers are higher. The increase in costs is mainly caused by the prescribing of biological drugs. If this therapeutic procedure is not applied, the costs on the part of the health care provider, reach the maximum amount of CZK 143,399.60. It must also be mentioned that the time of treatment was calculated based on published studies where the average survival time was 7.8 months. In reality, however, the health insurance company reimburses targeted drugs only after the progression of the disease may be manifested e.g. not earlier than after 20 months, which further significantly increases the actual costs. This also increases the reimbursements on the part of the health insurance company and, therefore, also the positive balance on the part of the health care provider.

With respect to the calculation of the smallcell lung cancer therapy, the provider again reaches a positive balance. The most significant financial benefit for the provider is in the case of a so-called limited disease (one of the forms of SCLC where radiotherapy plays an indispensable role). Radiotherapy significantly affects the resulting costs. In the calculation of the X-ray scheme for SCLC, for example, the health insurance company reimburses CZK 75,595, while the actual estimated costs amount to CZK 18,107. This difference allows the health care provider to compensate for the methods that may result in a negative balance owing to reimbursements. The situation is solved by the DRG system that corresponds more to the actual costs. The amounts of DRG reimbursements are presented in Tab. 3 .

The patient's co-payments represent above all, the so-called regulatory fees. These are incomes for health care facilities. If they exceed the limit set for a year (CZK 5,000, or CZK 2,500 for certain groups of patients in 2013), they are reimbursed to patients. This, however, does not affect the balance of the health care facilities.

\section{Conclusions}

The calculations above imply that treatment costs significantly differ depending on the selected diagnostic and therapeutic procedures. It also becomes apparent that the setting of the reimbursement system presently generates different stimuli for providers who may reach both positive and negative balances. This fact, in turn, may have an effect on the economic result leading as a consequence thereof, to the preference of alternatives more suitable in terms of reimbursement regardless of the optimum procedures for the particular patient. This fact is, to some extent, reflected by reimbursements calculated by means of the DRG system. The existing legal regulations and relations between individual actors create a situation, whereby it is complicated to obtain full information for the calculation of costs. Therefore, the costs on the part of the provider presented here are expert estimates based partly on publicly available sources and partly on expert opinions, which is a limiting factor with respect to the above calculations. We are of the opinion that the resulting costs modelled and presented in this study may truly reflect the situation in Czech hospitals (see also [24]). In the same way, we may assume that there are differences among health care providers both with respect to the specific costs and to those declared to assess such working costs that will give rise to accurate calculations for a particular hospital and a respective type of care in general.

The authors (Jana Šimrová and Vladimír Rogalewicz) acknowledge financial support for the development of HTA methods by the Ministry of Health of the Czech Republic under 
Grant No. NT11532 „Medical Technology Assessment".

\section{References}

[1] BANZ, K., BISCHOFF, H. et al. Comparison of treatment costs of grade $3 / 4$ adverse events associated with erlotinib or pemetrexed maintenance therapy for patients with advanced non-small-cell lung cancer (NSCLC) in Germany, France, Italy, and Spain. Lung Cancer. 2011, Vol. 74, No. 3, pp. 529-534. ISSN 0169-5002.

[2] Bodník [online]. Dan Ohnesorg, 2011 [cit. 2013-02-20]. Available from: http://www.bodnik.cz. [3] CHANG, S., LONG, S.R., et al. Estimating the Cost of Cancer: Results on the Basis of Claims Data Analyses for Cancer Patients Diagnosed With Seven Types of Cancer During 1999 to 2000. Journal of Clinical Oncology. 2004, Vol. 22, No. 17, pp. 3524-3530. ISSN 0732-183X.

[4] CHOUAID, C., ATSOU, K., et al. Economics of Treatments for Non-Small Cell Lung Cancer. Pharmacoeconomics. 2009, Vol. 27, No. 2, pp. 113-125. ISSN 1170-7690.

[5] ČOUPKOVÁ, H. Nemalobuněčný bronchogenní karcinom [online]. Brno: Masaryk Memorial Cancer Institute, 2011 [cit. 2013-02-20]. 11 p. (PDF). Available from: http://www.mou.cz/2-1nemalobunecny-bronchogenni-karcinom/f76.

[6] CIPRIANO, L.E., ROMANUS, D., EARLE, C.C., et al. Lung cancer treatment costs, including patient responsibility, by disease stage and treatment modality, 1992 to 2003. Value in Health. 2011, Vol. 14, No. 1, pp. 41-52. ISSN 1098-3015. [7] CZECH NATIONAL BANK. Central bank exchange rate fixing, 2013 [online]. Praha: ČNB, 2013 [cit. 2013-02-20]. Available from: http://www.cnb.cz/en/.

[8] CZECH REPUBLIC. Decree No. 475/2012 Coll., which fixes the value of a point, reimbursement limits for covered services, and regulation limits for 2013. Sbírka zákonů. Česká republika 2012, №. 178, pp. 6258-6338. ISSN 1211-1244.

[9] DEDES, K.J., SZUCS, T.D., et al. Management and costs of treating lung cancer patients in a university hospital. Pharmacoeconomics. 2004, Vol. 22, No. 7, pp. 435-444. ISSN 1170-7690.

[10] DEMOS EUROPA. Towards a sustainable and outcome-driven healthcare: effective healthcare systems at a time of fiscal austerity [online]. V4 Multi-stakeholder Dialogue Warsaw Meeting, Session report, 13-14 December 2011 [cit. 2013-12-15]. Available from: http://www.demos europa.eu/index.php?option=com_content\&view= article \&id=1007: towards-a-sustainable-andoutcome-driven-healthcare \&catid $=130: 2011$ events\&ltemid $=155 \&$ lang $=e n$.

[11] FERNANDEZ, R.L., et al. Economic burden of cancer Gross the European Union: a population based cost analysis. The Lancet Oncology. 2013, Vol. 14, Iss. 12, pp. 1164-1174. ISSN 1470-2045. [12] DOLEŽAL, T., PÍSAŘíKOVÁ, Z., ZEMANOVÁ, P., BARTÁŠKOVÁ, D. Costs of Type II Diabetes in the Conditions of the Czech Republic's Medical Care System. Vnitrni Lek. 2009, Vol. 55, pp. 342-344. ISSN 0042-773X.

[13] HESERAU, D., et al. Consolidated Health Economic Evaluation Reporting Standards (CHEERS) Statement. Value in Health. 2013, Vol. 16, pp. e1-e5. ISSN 1098-3075.

[14] JOSHI, A.D., CARTER, J.A., et al. Costeffectiveness of zoledronic acid in the management of skeletal metastases in patients with lung cancer in France, Germany, Portugal, the Netherlands, and the United Kingdom. Clinical Therapeutics. 2011, Vol. 33, No. 3, pp. 291-304.e8. ISSN 0149-2918.

[15] KUTÍKOVÁ, L., BOWMAN, L., et al. The economic burden of lung cancer and the associated costs of treatment failure in the United States. Lung Cancer. 2005, Vol. 50, No. 2, pp. 143-154. ISSN 0169-5002.

[16] MAŠKOVÁ, E. Wages and salaries in health services in 2011 [online]. Praha: ÚZIS, Aktuální informace, 2012. Vol. 30 [cit. 2013-02-20]. Available from: http://www.uzis.cz/rychle-informace/ mzdy-platy-ve-zdravotnictvi-roce-2011.

[17] MOLINIER, L., COMBESCURE, C., et al. Cost of lung cancer - A methodological review. Pharmacoeconomics. 2006, Vol. 24, No. 7, pp. 651-659. ISSN 1170-7690.

[18] NRC [online]. Praha: Národní referenční centrum, 2003 [cit. 2013-04-30]. Available from: http://www.nrc.cz/.

[19] OECD. Cancer Care: Assuring Quality to Improve Survival. Paris: OECD, 2013. 163 p. ISBN 978-92-64-180963.

[20] PETERA, J. Guidelines for treatment of nonsmall-cell lung cancer: Standard treatment procedure version 2013 [online]. Hradec Králové: Clinic of Oncology and Radiotherapy, University Hospital Hradec Králové, 2013 [cit. 2013-04-30]. 10 p. (PDF). Available from: www.fnhk.cz/fs880/ nemalobunecny-karcinom-plic.pdf.

[21] PETERA, J. Guidelines for treatment of smallcell lung cancer: Standard treatment procedure version 2013 [online]. Hradec Králové: Clinic of 
Oncology and Radiotherapy, University Hospital Hradec Králové, 2013 [cit. 2013-04-30]. 4 p. (PDF). Available from: www.fnhk.cz/fs879/ malobunecny-karcinom-plic.pdf.

[22] PHUNMANEE, A., WIRASORN, K., et al. Lung cancer in hospitalized patients of Thailand. Journal of the Medical Association of Thailand. 2012, Vol. 95, Iss. 7, pp. S201-S205. ISSN 0125-2208.

[23] POMPEN, M., GOK, M., et al. Direct costs associated with the disease management of patients with unresectable advanced non-smallcell lung cancer in The Netherlands. Lung Cancer. 2009, Vol. 64, No. 1, pp. 110-116. ISSN 0169-5002. [24] ROGALEWICZ, V., ŠIMROVÁ, J., et al. The Analysis of Costs and Reimbursements for Lung Cancer Treatment in the Czech Republic. Value in Health. 2013, Vol. 16, No. 7. pp. A407. ISSN 1098-3015.

[25] SCHILLER, J., TILDEN, D., et al. Retrospective cost analysis of gemcitabine in combination with cisplatin in non-small cell lung cancer compared to other combination therapies in Europe. Lung Cancer. 2004, Vol. 43, No. 1, pp. 101-112. ISSN 0169-5002.

[26] ŠIMROVÁ, J. Economic analysis of lung cancer therapy. Master Thesis. Kladno: Fakulta biomedicínského inženýrství ČVUT v Praze, 2013. $120 \mathrm{p}$.

[27] STANISIC, S., BISCHOFF, H.G., et al. Societal cost savings through bevacizumab-based treatment in non-small cell lung cancer (NSCLC). Lung Cancer. 2010, Vol. 69, No. Suppl. 1, pp. S24S30. ISSN 0169-5002.

[28] ÚZIS ČR, NOR ČR. Cancer Incidence 2010 in the Czech Republic [online]. Praha: ÚZIS, 2013 [cit. 2013-06-10]. Available from: http://www.uzis.cz/ en/publications/cancer-incidence-2010. ISBN 978-80-7472-034-5.

[29] VERGNENÈGRE, A., MOLINIER, L., et al. The Cost of Lung Cancer Management in France from the Payor's Perspective. Disease Management \& Health Outcomes. 2006, Vol. 14, No. 1, pp. 55-67. ISSN 1173-8790.

[30] VOJTÍŠEK, R., FÍNEK, J. Current recommendations for planning radiotherapy for non-small cell lung cancer. Studia Pneumologica et Phthiseologica. 2012, Vol. 72, No. 3, pp. 151-158. ISSN 1213-810X.
[31] VOJTÍŠEK, R., HAVRÁNEK, K., FÍNEK, J. The Use of PET/CT Fusion in Radiotherapy Treatment Planning of Non-Small-Cell Lung Cancers. Klinická Onkologie. 2011, Vol. 24, No. 1, pp. 23-34. ISSN 0862-495X.

[32] WHO. Cancer. Fact Sheet No. 297 [online]. Copenhagen: WHO, 2013 [cit. 2013-06-06]. Available from: http://www.who.int/mediacentre/ factsheets/fs297/en/.

[33] WOLSTENHOLME, J.L., WHYNES, D.K. The hospital costs of treating lung cancer in the United Kingdom. British Journal of Cancer. 1999, Vol. 80, No. 1-2, pp. 215-218. ISSN 0007-0920.

[34] ZENG, X, et al. The Cost of Treating Advanced Non-Small Cell Lung Cancer: Estimates from the Chinese Experience. PLOS ONE [online]. 2012, Vol. 7, Iss. 10 [cit. 2013-01-11]. Available from: http://www.plosone.org/article/info\%3Adoi $\% 2 \mathrm{~F} 10.1371 \% 2 \mathrm{Fjournal}$.pone.0048323. ISSN 1932-6203.

Ing. Jana Šimrová

Czech Technical University in Prague Faculty of Biomedical Engineering CzechHTA, Department of Biomedical Technology and

University Hospital Plzeň

Department of Oncology and Radiotherapy jana.simrova2107@gmail.com

PhDr. Miroslav Barták, Ph.D. Jan Evangelista Purkyně University Faculty of Social and Economics Studies

Department of Social Work miroslav.bartak@ujep.cz

MUDr. Radovan Vojtíšek University Hospital PIzeň

Department of Oncology and Radiotherapy vojtisekr@fnplzen.cz

doc. Vladimír Rogalewicz, CSc. Czech Technical University in Prague

Faculty of Biomedical Engineering CzechHTA, Department of Biomedical Technology rogalewicz@ fbmi.cvut.cz 


\section{Abstract}

\section{THE COSTS AND REIMBURSEMENTS FOR LUNG CANCER TREATMENT AMONG SELECTED HEALTH CARE PROVIDERS IN THE CZECH REPUBLIC Jana Šimrová, Miroslav Barták, Radovan Vojtíšek, Vladimír Rogalewicz}

The objective of the article is to objectivise and assess the costs for the lung cancer therapy from the payer's (health insurance company) and the healthcare provider's (hospital) perspective based on information available from several large hospitals and specialised centres. No comprehensive assessment of costs related to the treatment of lung cancers at all stages has been published in the Czech Republic to-date. The results in this study are calculated based on diagnostic and therapeutic algorithms, i.e. process maps. These, in turn, are derived from the recommended therapeutic procedures issued by the Masaryk Institute of Oncology, the University Hospital in Hradec Králové and the University Hospital in Plzeñ. In total, the costs and reimbursements were calculated for 32 utilized algorithms, i.e. process maps. The costs for therapeutic processes account for 22 results, while 10 results correspond to diagnostic processes. Both direct and indirect costs were included in individual calculations. The calculations imply that treatment costs significantly differ depending on the selected diagnostic and therapeutic procedure. It becomes apparent that the setting of the reimbursement system presently generates different stimuli for providers, who may reach both positive and negative balances. This fact, in turn, may have an effect on the economic result leading, in its consequence, to the preference of more suitable alternatives in terms of reimbursement regardless of the optimum procedures for the particular patient. This fact is, to a certain extent, reflected by the reimbursements calculated by means of the DRG system. The given algorithms may potentially be used by health care providers to reach working costs, which will allow accurate calculations for particular hospitals.

Key Words: Lung cancer, healthcare costs, process maps, health care reimbursement.

JEL Classification: 112.

DOI: 10.15240/tul/001/2014-3-007 